\title{
Multi-Decadal Deltaic Land-Surface Changes: Gauging the Vulnerability of a Selection of Mediterranean and Black Sea River Deltas
}

\author{
Edward J. Anthony ${ }^{1, *}$, Manon Besset ${ }^{2}$, Florin Zainescu ${ }^{3,4}{ }^{(\mathbb{D}}$ and François Sabatier ${ }^{1}$ \\ 1 CNRS, IRD, INRA, Coll France, CEREGE, Aix Marseille University, 13545 Aix-en-Provence, France; \\ sabatier@cerege.fr \\ 2 i-Sea, Bordeaux Technowest, 25 rue Marcel Issartier, 33700 Mérignac, France; manon.besset@i-sea.fr \\ 3 CNRS, ITES, Université de Strasbourg, UMR 7063, 5 rue Descartes, 67084 Strasbourg, France; \\ zaiflorin@gmail.com \\ 4 GEODAR Research Center, Faculty of Geography, University of Bucharest, 1 N. Bălcescu, \\ 01004 Bucharest, Romania \\ * Correspondence: anthony@cerege.fr
}

Citation: Anthony, E.J.; Besset, M.; Zainescu, F.; Sabatier, F.

Multi-Decadal Deltaic Land-Surface Changes: Gauging the Vulnerability of a Selection of Mediterranean and Black Sea River Deltas. J. Mar. Sci. Eng. 2021, 9, 512. https://doi.org/ 10.3390/jmse9050512

Academic Editor: Duccio Bertoni

Received: 16 April 2021

Accepted: 5 May 2021

Published: 9 May 2021

Publisher's Note: MDPI stays neutral with regard to jurisdictional claims in published maps and institutional affiliations.

Copyright: (c) 2021 by the authors. Licensee MDPI, Basel, Switzerland. This article is an open access article distributed under the terms and conditions of the Creative Commons Attribution (CC BY) license (https:// creativecommons.org/licenses/by/ $4.0 /)$.

\begin{abstract}
Areal changes over delta surfaces determined by land and water ratios are a promising tool for identifying spatial and temporal changes in deltas that may reveal subsidence and shoreline erosion. Such changes can also provide the basis for more detailed studies on variations in landcover and vegetation. Changes in land and water areas over a 35-year period (1984-2019) were determined for a selection of ten river deltas in the Mediterranean (Nile, Rhône, Po, Ebro, Moulouya, Ceyhan-Seyhan, Medjerdja, Ombrone, Arno) and the Black Sea (Danube), with a particular focus on aspects of subsidence and shoreline erosion. With the exception of the Ombrone, Arno, and Moulouya, and to lesser extent the Medjerdja, where notable changes dominate in the coastal zone and are tantamount to net erosion, the spatial pattern is largely dominated by delta-plain changes characterized by increasing areas of water. The pattern reflects a mix of shoreline erosion, land-use and land-cover changes, such as the ecological restoration of wetlands, but also increasing subsidence in these deltas, all of which have been exposed to a declining fluvial sediment supply due to human influence. The use of data on land-water ratios needs to be complemented by more detailed studies devoted to each delta in order to clearly disentangle changes related to land-use, vegetation, and subsidence. It is also important to determine how wetlands are interpreted in such ratios, as these important ecological elements are sensitive to ratio variations. It would also be interesting in future studies to examine how these variations play out over time, notably in deltas where changes have been significant over the period 1984-2019.
\end{abstract}

Keywords: river deltas; delta vulnerability; land-water changes; delta subsidence; river dams; Mediterranean Sea; Black Sea

\section{Introduction}

River deltas strongly depend on fluvial sediment supply that is increasingly impacted by human activities. Reduced sediment supply to deltas can lead to situations where natural subsidence is no longer balanced by delta-plain accretion, potentially generating an increase in delta wetland area [1], meaning delta shorelines become more vulnerable to wave and storm erosion [2]. The inability of sediment supply to balance subsidence can be expressed by increased conversion of land areas to wetlands subject to more or less prolonged seasonal-to-permanent flooding. Eroding delta beaches and barriers can also be affected by a lowering of their elevation relative to sea level and storm surges, especially where accelerated subsidence occurs.

These changes can have dramatic consequences on the socio-ecological systems that, today, characterize the relationship between deltas and the societies they support [3-5], 
including the deterioration and eventual disappearance of various ecosystem services provided by deltas, such as clean water, habitat, biodiversity, and storm mitigation. The difficulties of correctly measuring changes in delta surface elevation over large tracts of a delta plain mean that analytical studies of delta changes commonly resort to shoreline variations identified from increasingly available and higher-resolution satellite images [6], which enable relatively consistent monitoring [2]. While shoreline erosion can be an adequate yardstick for measuring delta vulnerability, such vulnerability can also be commonly expressed by areal changes in deltaic land and water ratios, and associated variations in wetlands because of the link between such changes and subsidence. The premise of this paper is thus to explore to what extent such changes in land and water ratios can be used as tools for gauging potential delta susceptibility to both overall subsidence and shoreline erosion. Changes in land and water ratios can also provide the basis for more detailed studies on temporal and spatial variations in land-use and vegetation. An increasing/decreasing trend in the water surface areas of delta plains can, indeed, be an indication of increasing/decreasing vulnerability of deltas in the face of future changes. Here, we use land-water change data determined from a database of spatial change, the Global Surface Water explorer (GSW) [7], over a 35-year period, for a selection of nine Mediterranean deltas and one Black Sea delta (Figure 1), with the aim of exploring the relationship between such changes and aspects of delta vulnerability associated with shoreline erosion and accelerated subsidence. Shoreline changes for these ten deltas were initially determined by [8] using a classic shoreline fluctuation approach based on a temporal comparison of shore-normal transects. The choice of these deltas here is thus based on the possibility of comparing these land-water changes for the shoreline (tantamount to retreat or advance) with those determined by [8], who gauged the vulnerability status of these deltas by quantifying changes in delta protrusion area and delta protrusion angle, relative to delta mouths over 30 years (1984-2016). The rationale for choosing these two metrics by these authors was that, as sediment supply waned, increasing relative efficiency of waves and longshore currents led to progressive plan-view 'flattening' of the delta protrusion. This implies that erosion of the delta protrusion leads to shoreline straightening accompanied by alongshore redistribution of eroded deltaic sediments away from the delta mouth(s). The procedure does not require tricky calculations of longshore transport volumes and river 'influence'. Here, we show interesting complementary information on shoreline change that can be gained from using data generated by the spatial mapping of land-water changes, but also extend our analysis to the possibilities of gauging spatial changes on delta plains over time.

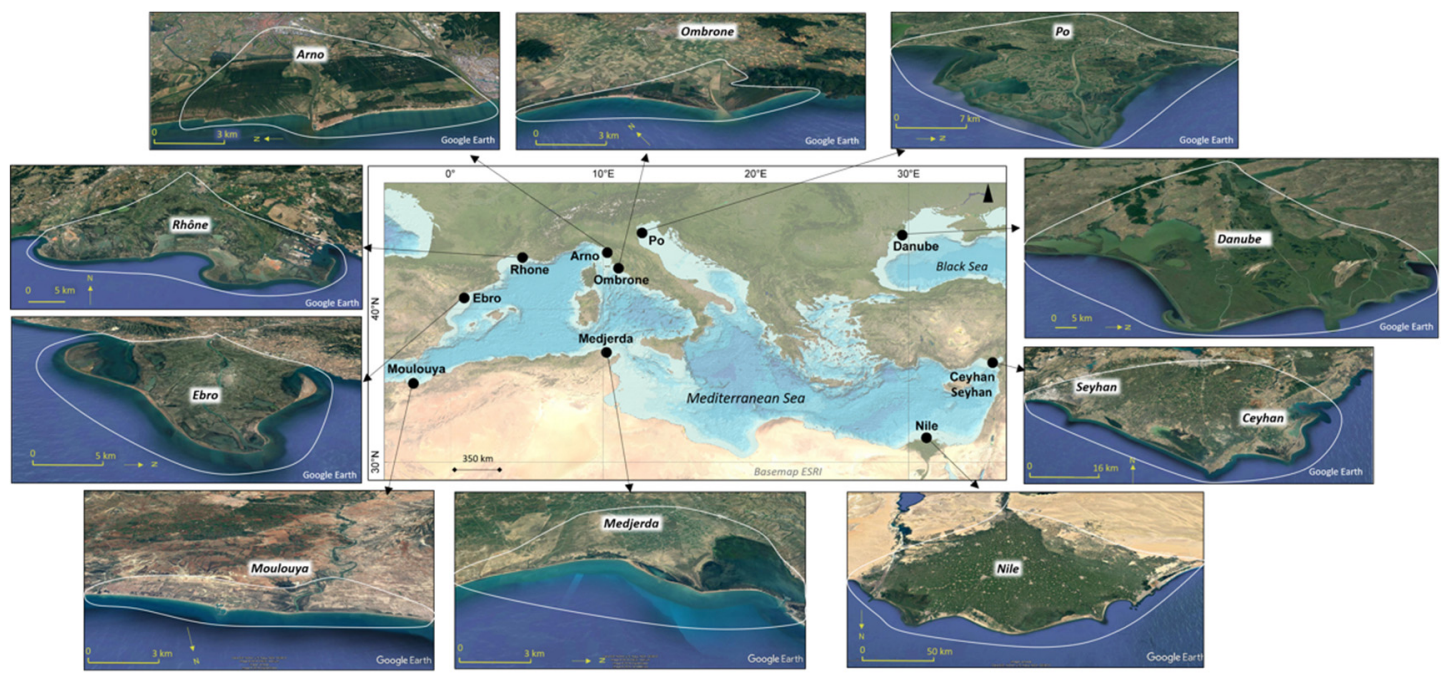

Figure 1. Map of the Mediterranean and Black Sea showing the ten river deltas selected for this study, and Google Earth images of each delta, with delimited buffers for the determination of land-water changes. The Ceyhan and Seyhan are considered here as a single delta. 


\section{Mediterranean River Deltas and Their Increasing Vulnerability}

Mediterranean deltas range from a few $\mathrm{km}^{2}$ in area, associated with small catchments (tens to hundreds of $\mathrm{km}^{2}$ ), to major multi-branched constructions at the mouths of the larger rivers, the most important of which are the Danube, the Po, the Nile, the Ebro, and the Rhône (Figure 1). The history and development of deltas in the Mediterranean basin, one of the cradles of civilization, has been strongly intertwined with the waxing and waning of cultures and societies and major climatic and economic changes over the last six millennia [9]. Anthropogenic pressures have been exerted on Mediterranean river catchments and deltas, notably via mediation of fluvial sediment flux, and these rivers are, today, among the most fragmented on Earth, with significant levels of loss of connectivity [10]. Sediment flux is an overarching component of management and conservation of coastal and deltaic systems, as sediments form the foundations for delta growth, mitigate natural subsidence, and enable delta sustenance in the face of sea-level rise. Some of the characteristics of the ten selected deltas are shown in Table 1. Many of these deltas are linked to river catchments that have been dammed over the last few decades, leading to significant reductions in fluvial sediment loads $[8,11]$. None of the river catchments feeding the ten deltas selected for this study have been spared by sediment reduction, caused mainly by dams (Figure 2).

Table 1. Selection of data on the ten deltas and on their catchments and river discharge, adapted from data culled by [8].

\begin{tabular}{|c|c|c|c|c|}
\hline & River Basin Area $\left(\mathrm{km}^{2}\right)$ & River Length (km) & Water Discharge $\left(\mathrm{m}^{3} / \mathrm{s}\right)$ & Delta Area from Apex $\left(\mathrm{km}^{2}\right)$ \\
\hline Arno & 9200 & 240 & 57 & 437 \\
\hline Ceyhan-Seyhan & 34,210 & 380 & 222 & 150 \\
\hline Danube & 779,500 & 2536 & 6499 & 5560 \\
\hline Ebro & 85,100 & 624 & 240 & 935 \\
\hline Medjerda & 15,930 & 370 & 18 & 209 \\
\hline Moulouya & 51,000 & 520 & 21 & 787 \\
\hline Nile & $3,038,100$ & 3878 & 2778 & 12,512 \\
\hline Ombrone & 3480 & 130 & 32 & 37 \\
\hline Po & 87,100 & 691 & 1514 & 948 \\
\hline Rhône & 90,000 & 820 & 1700 & 3194 \\
\hline
\end{tabular}

Eight of the ten deltas are associated with catchments that have lost more than $60 \%$ of their sediment flux. The Ombrone, Rhône, Ebro, Moulouya, and Nile deltas have lost more than $80 \%$ of the total fluvial loads they usually receive; this level attaining $98 \%$ in the Ebro and the iconic case of the Nile. The sediment load of the Danube is still relatively high, at $19.6 \mathrm{Mt} /$ year, despite a $70 \%$ drop after the construction of the Iron Gate dams. The Ceyhan catchment, the latest to be affected by dams, has also lost a significant amount of its fluvial sediment flux. Although the relationship between dams and river sediment flux reduction appears, as expected, to be the overarching element of river catchment management in the Mediterranean and Black Seas in recent decades, there is a spatial and temporal variability in this relationship that implies that other factors, including historical and cultural heritage, and the impacts of reforestation, especially in the European rivers, need to be considered $[8,9,12]$. A poor statistical relationship between change in delta protrusion area and reductions in sediment flux in eight out of the ten deltas led [8] to suggest that the effect of dams in causing delta shoreline erosion may have been over-estimated. This poor relationship could also imply a long time-lag in bedload removal and transport to the coast downstream of dams, and could also arise from bedload sequestering alongshore, within the confines of the deltas, by delta shoreline stabilization structures and/or compensated by delta spit lengthening in the microtidal, strongly wave-influenced, context of Mediterranean and Black Sea deltas. Other factors 
that may be affecting shoreline change in certain deltas include subsidence, sea-level rise, variations in storminess, episodic river floods, and engineered sediment releases below dams. River connectivity in the Mediterranean has been significantly impaired by engineering works aimed at torrent management and channel embanking to assure flood control and navigation. In-channel gravel and sand extractions have significantly affected the sediment budgets of most Mediterranean rivers, as shown by the example of the small Magra catchment (area: $1400 \mathrm{~km}^{2}$ ) in Italy, the lower reaches, river mouth, and adjacent subaqueous delta of which have been subject to almost total depletion of bedload as a result of massive extraction over the period 1882-2014 [13]. Changes in land and water areas, especially in the larger deltas, may not only reflect fluvial sediment load variations, but also various anthropogenic interventions, such as change in land use, landscape rewilding, meander engineering, and the construction of embankments, dikes and harbours.

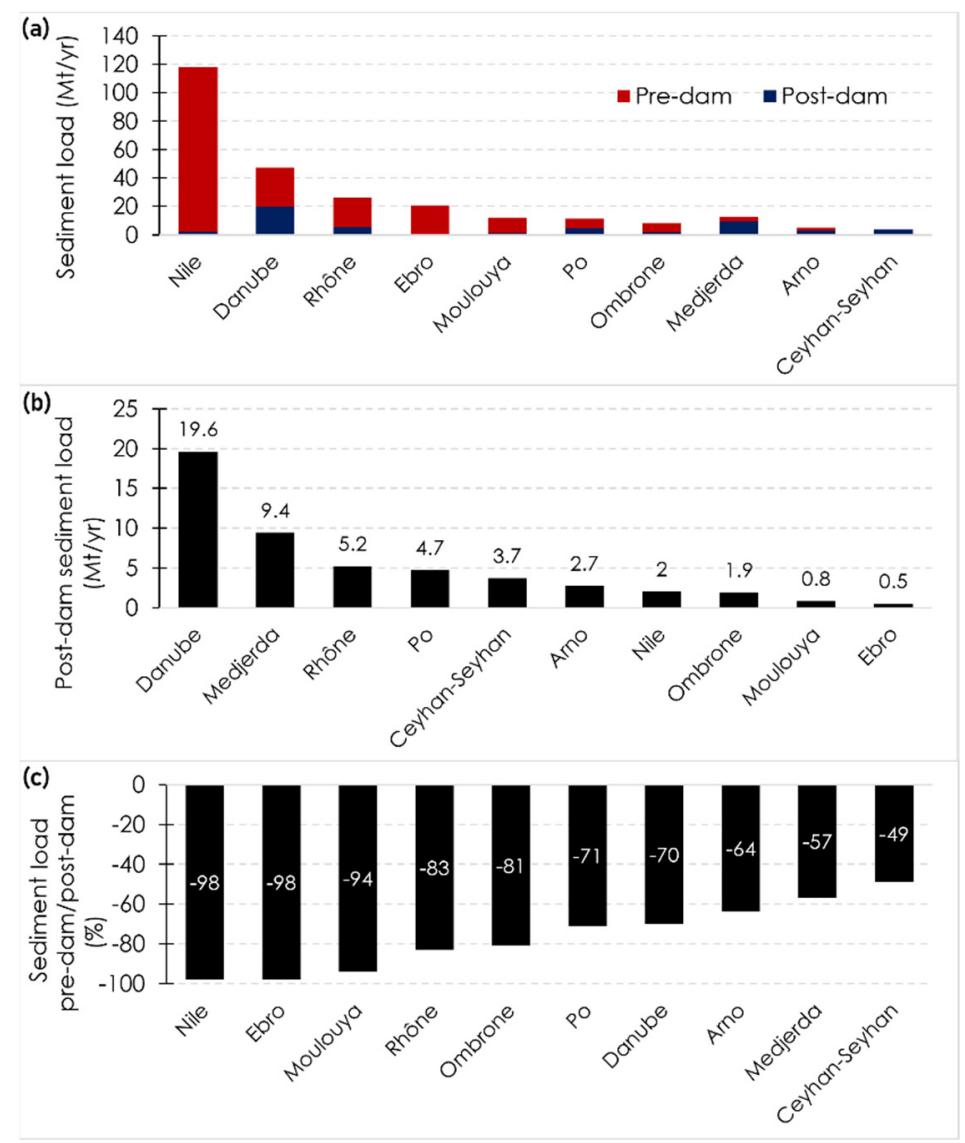

Figure 2. Graphs depicting changing total river sediment flux for the ten deltas in Mt/year (a); post-dam (post-1970) sediment flux in Mt/year (b); (c) percentage loss of sediment flux between pre-dam and post-dam periods. From data collated by [8].

\section{Materials and Methods}

Areas converted from land into water and vice versa can now be estimated from existing datasets in the literature. These include the GSW [7] and the Global Land Analysis and Discovery (GLAD) [14] datasets. Here, we use the GSW data which cover a longer period (1984-2019) than the GLAD data (1999-2019). The GSW data are derived using automated procedures on each pixel $\left(30 \times 30 \mathrm{~m}^{2}\right)$ of Landsat satellite images covering the 35-year period. We manually drew two sets of buffers for each delta: a larger buffer covering the entire delta plain, including coastal areas, shown in Figure 1, and a narrow coastal buffer representative of changes in the coastal zone. [2] successfully used the landwater conversion method as a complement to the identification of shoreline changes using classical methods based on successive shoreline detection from satellite images, and applied 
it to a selection of 51 world deltas. To achieve this, they defined an 'active coastal band', with a width of $2 \mathrm{~km}$ representing the potential shoreline bandwidth of change over a 30-year period (1984-2015). This width was chosen as a common reference, given the large number of deltas they analyzed, to represent the bandwidth of change liable to be caused by erosion (delta land loss) or accretion (delta land gain). The authors acknowledged, however, a number of limitations with this $2 \mathrm{~km}$-width, such as size and roughness of the shoreline and inclusion of water areas (lagoons) behind narrow shoreline barriers that could have silted up or been reclaimed, or land areas that have been transformed into wetlands. In this study, we improved on the previous methodology of [2] by carefully resorting to buffers in the coastal zone that capture only changes in the existing land at its margins with water. These buffers are therefore not shown in Figure 1, as their limits correspond to the changes in the land-water margins between 1984 and 2019. These changes are deemed to occur as a result of marine processes, such as waves and longshore currents and/or river-bank processes. These processes include the following: wave erosion of beaches and spits; sediment deposition in deltaic channels, along deltaic channel banks, and at river mouths; sediment deposition at spit tips and at the ends of littoral cells; and backbarrier deposition resulting from overwash-dominated retreat of coastal barriers.

Overall, we retained six conversion categories from the transition layer over the 35-year period of observation: (1) conversion of land into permanent water; (2) conversion of land into seasonal water; (3) conversion of seasonal water into permanent water; (4) conversion of permanent water into land; (5) conversion of seasonal water into land; and (6) conversion of permanent water into seasonal water. The first three categories are indicative of increasing spatial and/or temporal presence of water areas, and could lead to an increase in wetland area, whereas the last three are indicative of decreasing spatial and/or temporal water presence but with the maintenance of wetlands in category (6). These land-water datasets have limitations, however, especially with regard to the status and extent of vegetated wetlands, which are sensitive to these changes.

\section{Results}

The spatial patterns of land and water area changes over the ten deltas are shown in Figures 3-5. The percentages of coastal zone change relative to overall change are shown in Table 2. Spatial changes largely dominant on the delta plain (95\%-98\%), compared to the coastal zone, are displayed by the Nile, the Danube, and the Rhône (Figure 3), and to a lesser degree by the Po (78\%), Ebro (91\%), and Ceyhan-Seyhan (91\%) deltas (Figure 4). Significant changes in the coastal zone relative to overall delta change (Table 2) are characteristic of the smaller Ombrone (81\%), Arno (75\%), and Medjerdja (41\%) deltas (Figure 5), but the larger Moulouya delta is also in this category (61\%). The areas covered by these two spatial categories, delta plain and coastal zone, are depicted in Figure 6. The results show that, with the exception of the Danube, all delta plains are characterized by greater conversion of land into water than the other way round. The rankings in terms of overall water and land conversions show the most significant levels of conversion from land to water $(L \rightarrow W)$, including land into permanent water $(\mathrm{L} \rightarrow \mathrm{PW})$ in the Arno, with, respectively, $89 \%$ and $69 \%$, followed by the Ceyhan-Seyhan, respectively, with $72 \%$ and $55 \%$. The Merdjerda and Moulouya deltas show high $\mathrm{L} \rightarrow \mathrm{W}$ levels of $78 \%$ and $75 \%$, but a more seasonal pattern with only $32 \%$ and $36 \%$ of LPW. Only the Danube shows a higher water to land $(\mathrm{W} \rightarrow \mathrm{L})$ change than $\mathrm{L} \rightarrow \mathrm{W}$, with only $10 \%$ of LPW, although this level is lower in the Ebro (5\%) and the Rhône $(7 \%)$. The results are similar for the coastal zone, but rates of $\mathrm{L} \rightarrow \mathrm{W}$ conversions exceeding $50 \%$ are shown by all the deltas except the Danube (Figure 6 ). The coastal zones of the Moulouya, Ceyhan, Arno, and Nile show a trend towards more water areas that exceed $70 \%$. The values decrease gradually but are above $50 \%$ in the Ombrone, Ebro, Medjerdja, and Rhône. 


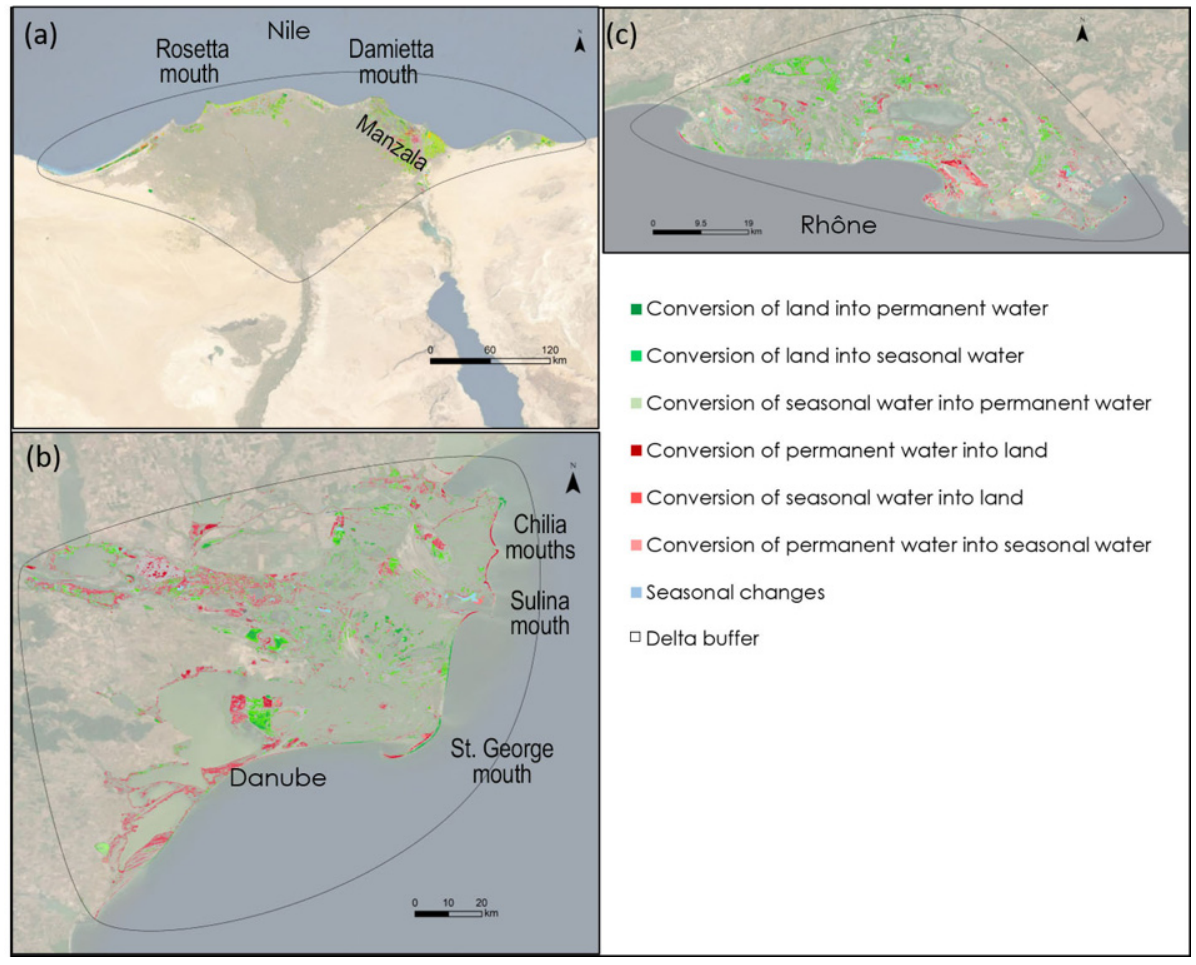

Figure 3. Maps of categories of land $\rightarrow$ water and water $\rightarrow$ land conversions for the Nile (a), Danube (b), and Rhône deltas (c), culled from the Global Surface Water (GSW) database [7]. The spatial pattern is largely dominated by delta-plain change (91\%-95\%). Basemap: Esri, DigitalGlobe, GeoEye, Earthstar Geographics, CNES/Airbus DS, USDA, USGS, AeroGRID, IGN, and the GIS User Community.

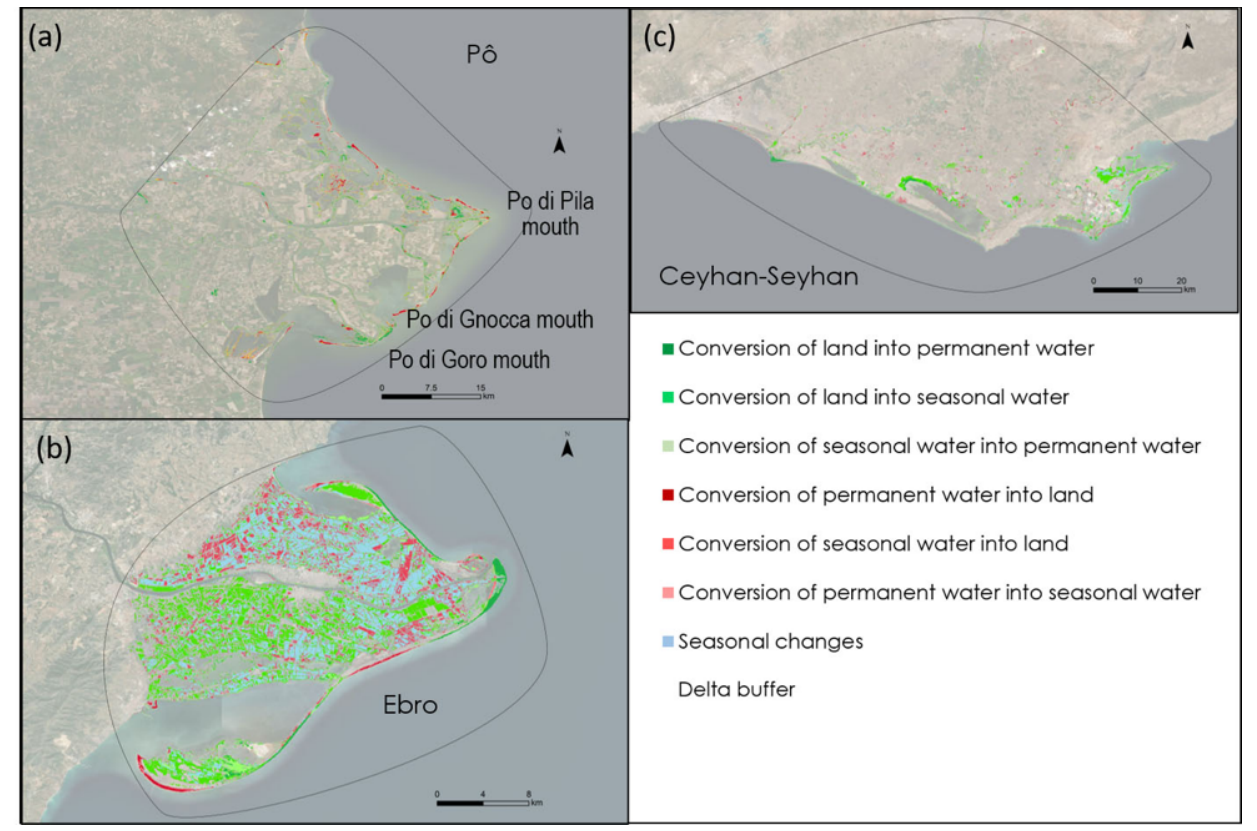

Figure 4. Maps of categories of land $\rightarrow$ water and water $\rightarrow$ land conversions for the Po (a), Ebro (b), and Ceyhan-Seyhan deltas (c), culled from the Global Surface Water (GSW) database [7]. The spatial pattern shows relatively strong (78\%-91\%) delta-plain changes. Basemap: Esri, DigitalGlobe, GeoEye, Earthstar Geographics, CNES/Airbus DS, USDA, USGS, AeroGRID, IGN, and the GIS User Community. 


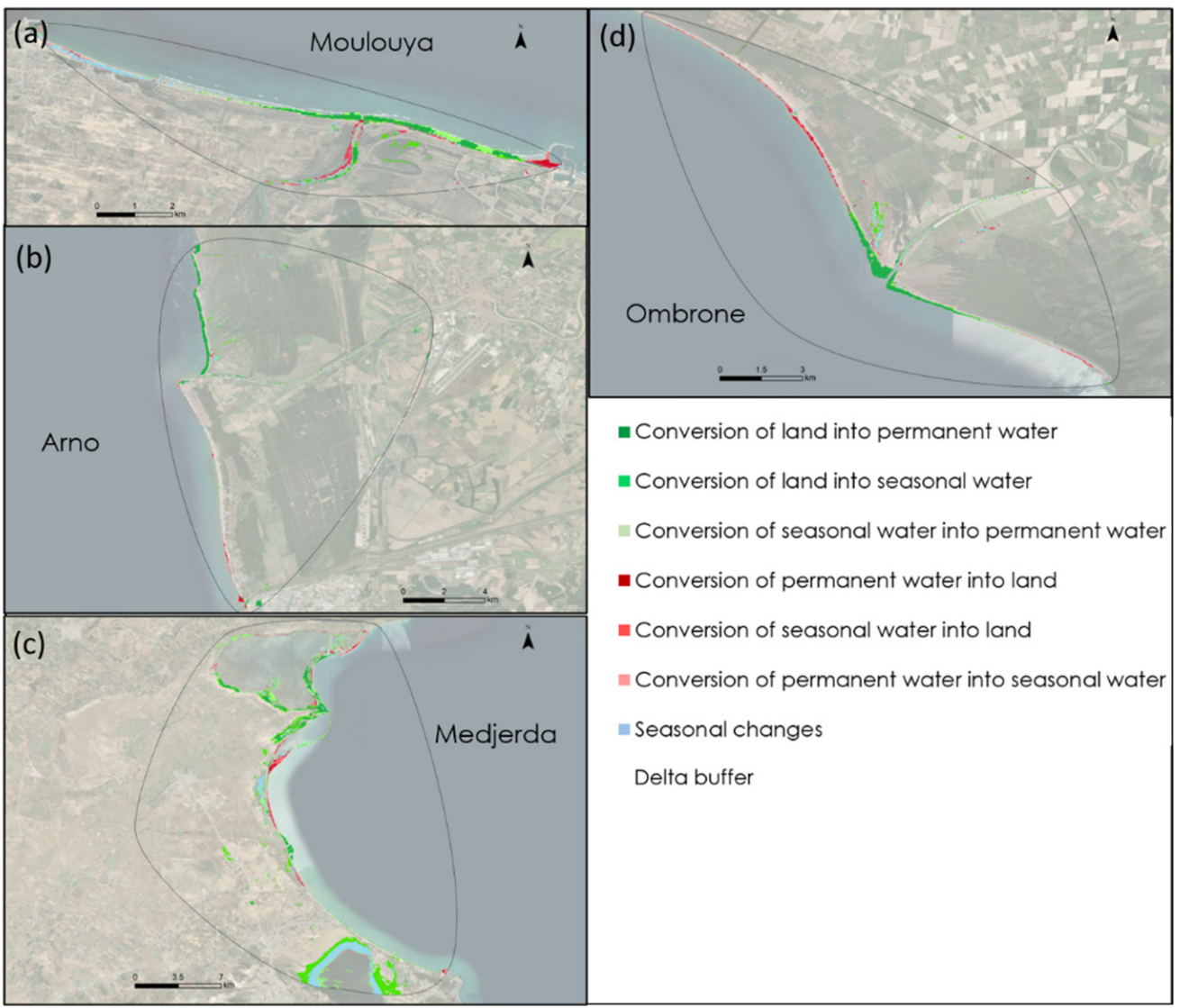

Figure 5. Maps of categories of land $\rightarrow$ water and water $\rightarrow$ land conversions for the Moulouya (a), Arno (b), Medjerdja (c), and Ombrone deltas (d), culled from the Global Surface Water (GSW) database [7]. The spatial pattern shows a strong coastal zone component $(40 \%-80 \%)$, relative to the entire delta plain. Basemap: Esri, DigitalGlobe, GeoEye, Earthstar Geographics, CNES/Airbus DS, USDA, USGS, AeroGRID, IGN, and the GIS User Community.

Table 2. Percentages of the contribution of GSW change in the coastal zone of the ten deltas relative to overall delta GSW change.

\begin{tabular}{lr}
\hline Ombrone & 81 \\
\hline Arno & 75 \\
\hline Moulouya & 61 \\
\hline Medjerdja & 41 \\
\hline Po & 22 \\
\hline Ebro & 9 \\
\hline Ceyhan-Seyhan & 9 \\
\hline Danube & 5 \\
\hline Rhône & 5 \\
\hline Nile & 2 \\
\hline
\end{tabular}




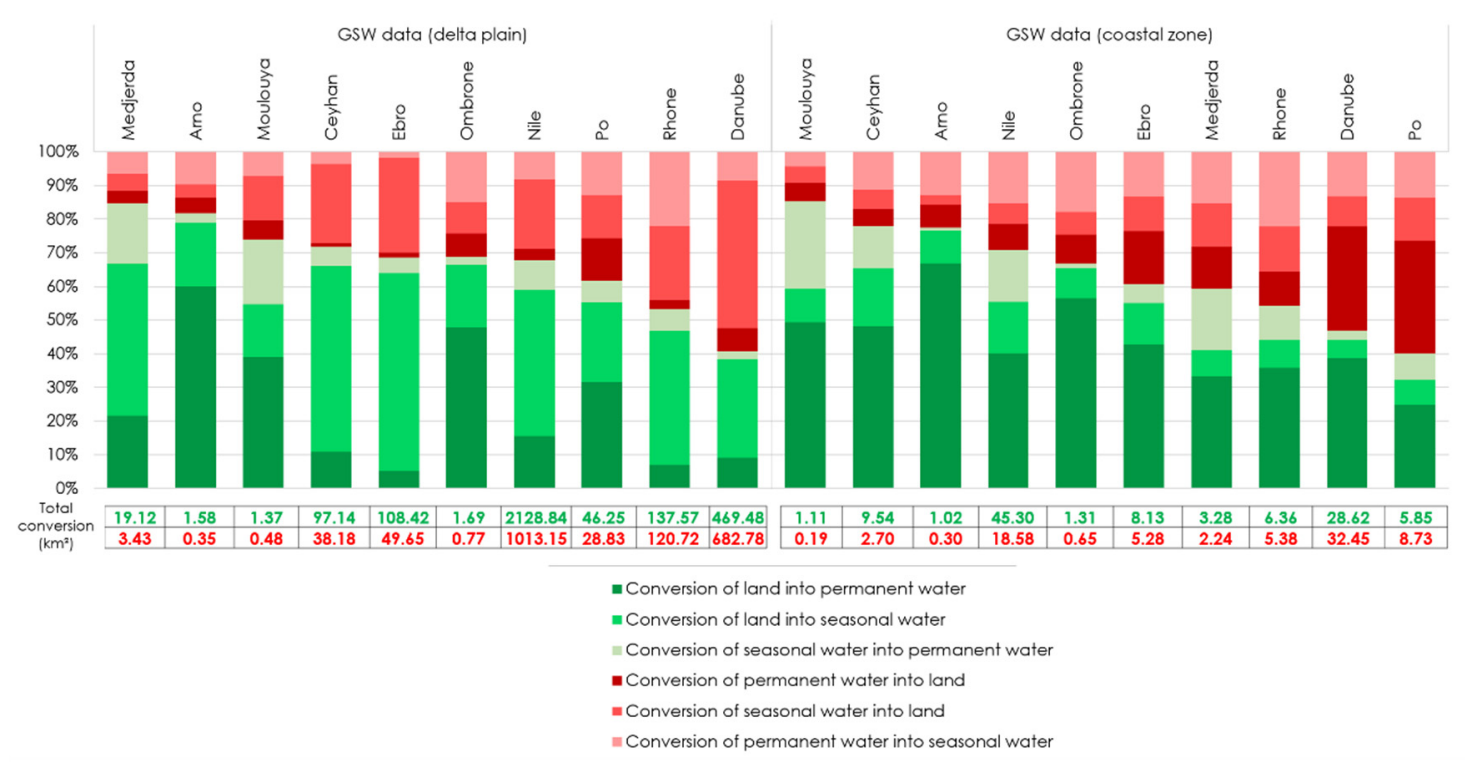

Figure 6. Percentages of various categories of land $\rightarrow$ water and water $\rightarrow$ land conversions for the ten delta plains and their coastal zones.

\section{Discussion}

With the exception of the Ombrone, Arno, and Moulouya, where land and water conversions in the coastal zone exceed $60 \%$ of the total conversions over the entire delta, change is very largely spread over the delta plains (Table 2). This change also reflects increasing areas of water (Figures 3 and 4), with the exception of the Danube (Figure 6). The preponderance of land-water changes on the delta plains compared to the coastal zones represents a preliminary degree of filtering of the data, and appears to be influenced to some degree by delta size. The highest percentage $(81 \%)$ of coastal zone-dominated change corresponds to the smallest delta, the Arno (Table 1). This trend suggests that the small deltas (Arno, Ombrone, Medjerdja) are more proportionately exposed to larger shoreline changes, essentially erosion in this case, than the larger deltas, in agreement with [2] on a large selection of the world's deltas. The case of the bigger Moulouya river and its delta, which stands out as an exception in this category (Figure 5a), is interesting. The Moulouya and the Medjerdja are the only rivers with deltas showing a clear statistical relationship between area loss and decrease in the fluvial load [8]. The coastal zone of the Moulouya has a long history of retreat. The protrusion at the mouth and the adjacent beaches and dunes were eroded to the tune of $0.8 \mathrm{~km}^{2}$ between 1958 and 1986, following the construction of the first dams on this river [15], and this loss has continued to the present day, as shown by [8] and the present study.

The spatial patterns should reflect a mix of shoreline erosion and delta-wide landcover changes, such as the ecological restoration of wetlands, but also probably increasing subsidence, as the sediment supply has significantly declined with no exception (Figure 2). The question of subsidence is of particular interest regarding land-water changes. In the Nile delta, although change in the coastal zone represents only a very low proportion $(2 \%)$ of the overall change (given the large area of this delta (Table 1)), the $\mathrm{L} \rightarrow \mathrm{W}$ change is consistent with the spatial pattern of subsidence identified by $[16,17]$. Subsidence is most pronounced in the coastal zone of the delta, especially in the Manzala area of the Damietta mouth (Figure 3a). Subsidence is further discussed below with reference to the well-known past accelerated sinking of the Po delta generated by human activities, and in a later section.

The case of the Po is interesting (Figure 4a). The Po seems to illustrate quite clearly delta resilience and recovery following important subsidence in the past, generated by extractive activities, as demonstrated by the study of [18], which attempts to unravel how shoreline fluctuations and delta subsidence have played out together. This is a delta with 
a still significant level of subsidence, although current rates are much lower than rates generated by accelerated subsidence prior to the 1970 s, due to methane-rich groundwater extraction [19]. More than $3 \mathrm{~m}$ of delta-surface sinking were recorded in places as a result of aquifer withdrawals, with maximum subsidence rates of more than $200 \mathrm{~mm} \mathrm{y}^{-1}$ in the central part of the delta [20]. With the closure of the wells in the early 1960s, the subsidence rate decreased almost instantly to $10-20 \mathrm{~mm} \mathrm{y}^{-1}$ [21]. The delta-wide $\mathrm{L} \rightarrow \mathrm{W}$ conversion over the last 35 years is high $(60 \%)$, and might be reflecting on-going subsidence, given the good overlap with subsidence data from 1992-2017 [21]. [19] showed that landform, vegetation, and land-use classes in the Po hardly varied over the period 1978-2015. The coastal zone, which accounts for $22 \%$ of the total area change over the delta (Table 2), seems to show, however, more resilience from subsidence than the rest of the delta plain. It has been characterized by larger net $\mathrm{W} \rightarrow \mathrm{L}$ conversion $(30 \%)$ than net $\mathrm{L} \rightarrow \mathrm{W}$ conversion $(13 \%)$. This suggests a good degree of recovery of the coastal fringe of this delta from accelerated subsidence, which must have affected the shoreface too as gas extractions were also carried out offshore. The propensity for larger $\mathrm{W} \rightarrow \mathrm{L}$ change in the coastal zone is consistent with the inner shoreface changes identified by [18], who showed accretion along much of the delta shoreline but ongoing retreat of the southernmost mouths (Po di Goro and Po di Gnocca). The recent subsidence and shoreline-change patterns of the Po clearly illustrate the intimate link between these two processes. Diminishing subsidence has been accompanied by a return to equilibrium or near-equilibrium shoreline positions $[18,22]$ that have replaced the rampantly retreating shorelines of the various delta sectors when anthropogenic subsidence was high. These changes are also reflected in recent aggradation of a mouth bar off the current main mouth of the Po, the Po di Pila [23]. The present land-water changes over the delta plain may reflect some degree of restoration of the Po fluvial sediment supply and changes in delta-plain depocenters associated with the net deceleration in human-induced subsidence.

The $\mathrm{L} \rightarrow \mathrm{W}(69 \%)$ change of the Ebro indicates both high levels of shoreline erosion in the same areas as those highlighted by [8], notably the mouth, but also updrift spit erosion and downdrift spit accretion (Figure 4b). Much of the change, however, concerns land to seasonal water $(\mathrm{L} \rightarrow \mathrm{SW}$ ) conversion on the delta plain, especially in the southern half of the delta, which is characterized by organic-rich sandy and fine-grained marsh and alluvial soils that undergo more compaction, and, therefore, more subsidence than the more sandy and silty alluvial soils of the northern half [24].

The Danube delta plain (Figure $3 b$ ) recorded an overall positive conversion of land relative to water (Figure 6). Unlike the other nine deltas, the Danube has been affected by numerous changes in the agricultural and ecological status of large areas over the last three decades [25,26]. For instance, [26] used a remote sensing approach to estimate that $25 \%$ of the delta is now affected by human interventions. Examples of such changes thus reflect a multitude of human activities and natural processes (Figure 7), including transformation of wetlands into agricultural fields that result in $\mathrm{W} \rightarrow \mathrm{L}$ conversion, or, conversely, wetland restoration and rewilding, involving inundation of previous agricultural lands or polders tantamount to $\mathrm{L} \rightarrow \mathrm{W}$ conversion. Although initially land and vegetation, such areas now converted predominantly to water may undergo localized subsidence. Many fish farms are now abandoned and converted to land with vegetation, whereas others have been re-infilled. Sediment supply-driven land changes are hard to disentangle from vegetation changes. Although there are hints of decreasing lake sizes near the apex of the Danube delta due to sediment influx, the majority of the lakes on the delta plain seem to be slowly increasing in size. It is tempting to attribute this to sea-level rise in the last decades, but the southern delta, comprising the large lagoons of Razelm-Sinoe, and which is known for high subsidence in the past [27], is actually recording decreasing open-water areas around the edges, quite clearly due to vegetation growth of the common reed Phragmites australis not related to sediment supply. The difficulties of disentangling some of these changes in the Danube delta using satellite images have been highlighted by [26]. Additionally, more localized interventions, such as engineered meander cuts on 
the St. George branch, have resulted in infilling of the meanders and contributed overall to positive land change (Figure 7a).
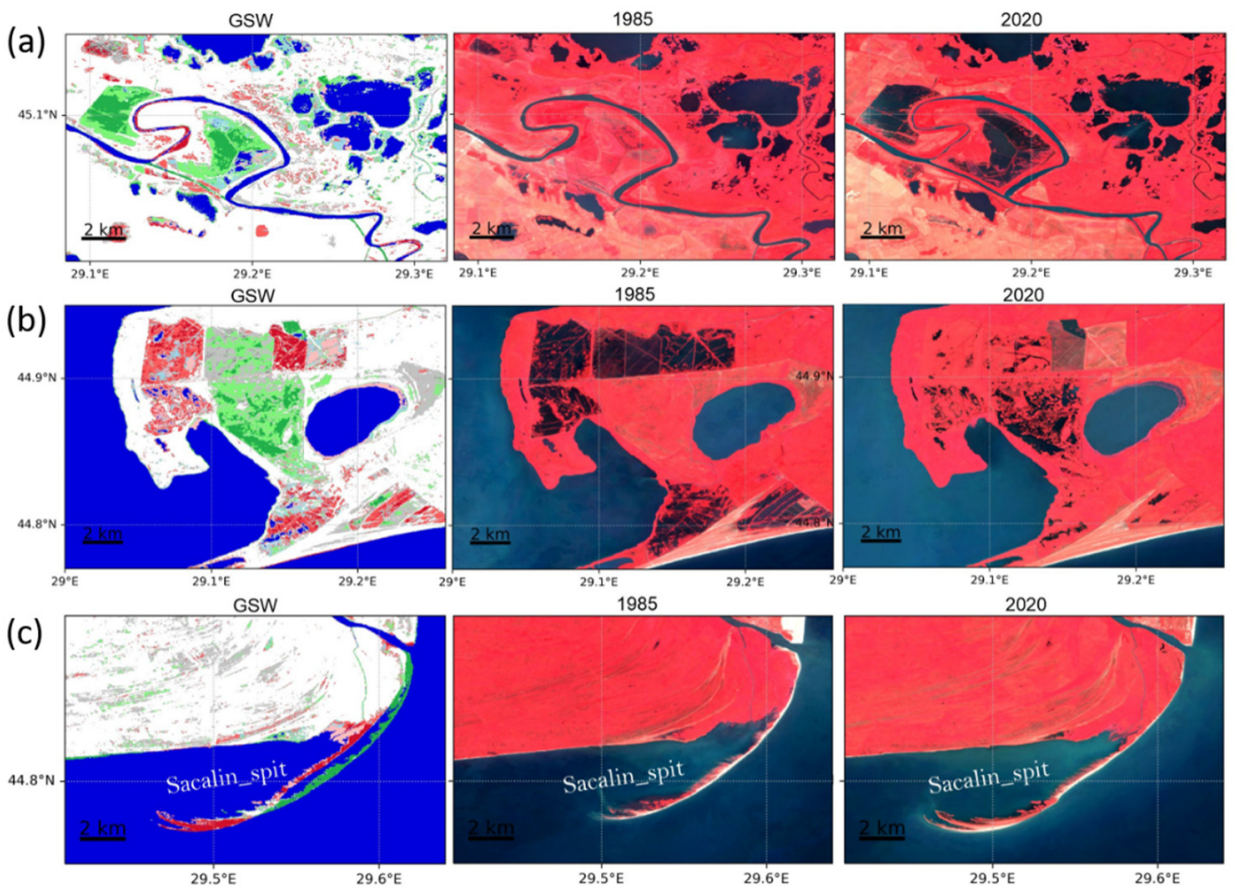

- Conversion of land into permanent water
" Conversion of land into seasonal water
"Conversion of seasonal water into permanent water

- Conversion of permanent water into land - Conversion of seasonal water into land

= Conversion of permanent water into seasonal water

Figure 7. Examples of GSW changes in the Danube delta between 1985 and 2020: (a) changes due to rewilding, meander cuts, and sediment supply on the Saint George branch; (b) changes due to land use and vegetation in the southern delta; (c) changes associated with the coastal dynamics of the Sacalin spit. Based on median Landsat images of all available cloudless images of each year.

The coastal zone shows a clear difference between the three current delta lobes (Figure $3 b$ ). In the north, the Chilia has a predominantly positive $\mathrm{W} \rightarrow \mathrm{L}$ change because it receives the bulk of the river's water and sediment, although damming is now responsible for the retreat of its northern (Oceakov) mouth. The construction of jetties at the Sulina mouth created a counter-drift which resulted in sediment supply from the erosion of the lobe in the south, whereas most of the river-supplied sediments are deposited south of the jetty-bound river mouth, creating a subaqueous mouth bar. Further south, the St. George lobe is undergoing erosion near the river mouth [28], but the littoral cell is characterized by sediment budget equilibrium due to the high growth in land area at the distal tip of the Sacalin spit. The Sacalin spit achieved one phase of rollover migration during this period [29], and registered one of the fastest rates of shoreline change recorded in any delta, as shown in Figure 7c. Part of this rapid change, associated with $\mathrm{L} \rightarrow \mathrm{W}$ conversion (land loss), is not captured by the GSW data, but was added in the calculation of the net coastal zone change (Table 2).

Importantly, [8] showed that the coastal zones of eight out of the ten selected deltas lost area over a period of 30 years, with a maximum, respectively, of $34.4 \%$ and $16.3 \%$ for the Moulouya and Medjerda deltas in North Africa, but they identified only relatively weak changes in the other deltas. With the exception of the Arno, these are also the two deltas that have undergone the highest levels of $\mathrm{L} \rightarrow \mathrm{W}$ conversion (respectively, $75 \%$ and $78 \%$ ). The $\mathrm{L} \rightarrow \mathrm{W}$ changes in the Ombrone, Arno, and Moulouya deltas are dominated by change in the coastal zone (Table 2). In the case of the Moulouya, this is tantamount to plan-view retreat of the mouth area and sediment redistribution on both flanks of the delta. The impact of shoreline engineering structures is clearly displayed by differential 
shoreline erosion and accretion. The high $\mathrm{L} \rightarrow \mathrm{W}$ levels of the Arno (89\%) and the Ombrone (71\%) also indicate significant rates of shoreline erosion on a coast beleaguered by problems of a fluctuating river sediment supply [30] and a fragmented longshore drift system characterized by several cells created by engineering structures to stave off erosion [31,32]. This is a pattern of disrupted sediment connectivity, involving both the river-to-coast continuum and increasingly engineered shorelines, that repeats itself throughout the Mediterranean [33]. In the Medjerda, where the coastal zone also accounts for a high proportion of total change $(41 \%)$, this change involves sediment redistribution alongshore, with erosion of the delta protrusion at the river mouth, as well as reworking of a probably abandoned lobe of the delta, accompanied by sectors of shoreline advance. In both the Moulouya and Medjerdja deltas, the $\mathrm{L} \rightarrow \mathrm{W}$ conversion also appears to involve significant erosion of the main delta channel banks.

Deltas with the largest protrusion losses are not those currently exhibiting the highest subsidence rates and there was no clear relationship between the 30-year loss in protrusion area and current subsidence rates [8]. However, these reported subsidence rates (Figure 8) need to be considered with caution, given the potentially large variability of this process in deltas and the difficulty of adequately gauging it. The highest subsidence rates are found in the Arno, for which the $\mathrm{L} \rightarrow \mathrm{W}$ change has essentially concerned shoreline retreat rather than the delta plain, where subsidence should normally be more pronounced. Compensation for subsidence no doubt takes up some of the subsisting fluvial sediment supply to the deltas, especially the fine-grained over-bank sediment. The Medjerda probably illustrates the moderating effect of a still relatively sustained sediment supply, despite dam construction, on a high subsidence rate of $10 \mathrm{~mm} /$ year. However, in some of the alluvial plains of these Mediterranean deltas, the possibility for river sediment flux to balance subsidence is being progressively curtailed by an increase in elevation of artificial channel embankments, as in the case of the Po.



Figure 8. Mean subsidence rates for the ten deltas collated from a synthesis by [8].

\section{Conclusions}

The spatial changes in land and water surfaces in a selection of ten Mediterranean and Black Sea deltas over the last thirty-five years highlight interesting tendencies in land-cover changes, but also vulnerability to subsidence and shoreline erosion. Such data are, thus, useful as tools in monitoring the potential direction of these changes (land-to-water or water-to-land). Trends shown by the coastal zones of the smaller deltas, such as the Arno and Ombrone, clearly point, for instance, to dominant shoreline retreat. However, the use of these land-water data must be considered as just one useful approach that needs 
to be complemented by more detailed studies devoted to each delta in order to clearly disentangle, within the delta-plain area, changes due to land use, vegetation, especially in wetland areas, and subsidence. A fine example is that of determining how wetlands are to be interpreted in changing land-to-water or water-to-land ratios, not just because wetlands are very sensitive to these variations but also because they are essential ecological elements in these deltas. Moreover, the assessment of change is presented here over a single time block between 1984 and 2019. It would be interesting in future studies to examine how these variations have played out over shorter periods, notably in deltas such as the Danube, where significant changes have occurred within the overall 35-year time span, but also with regards to the eventual restoration of fluvial sediment flux and its effect on delta resilience. The European Union's Water Framework Directive was enacted in 2000 on the protection, restoration and quality enhancement of European rivers. These objectives are based on a limitation of construction of new hydropower dams, removal of obsolete dams, and strict control of river-bed aggregate extractions.

Author Contributions: Conceptualization, E.J.A.; methodology, E.J.A., M.B., F.Z. and F.S.; writingoriginal draft preparation, E.J.A. and F.Z.; revision: E.J.A., M.B., F.Z. and F.S. All authors have read and agreed to the published version of the manuscript.

Funding: Florin Zainescu benefitted from the support of the Romanian Young Academy funded by Stiftung Mercator and the Alexander von Humboldt Foundation for the period 2020-2022. The research leading to these results has received funding from the Norway Grants 2014-2021, under Project contract no. 30/1 September 2020.

Institutional Review Board Statement: Not applicable.

Informed Consent Statement: Not applicable.

Data Availability Statement: Not applicable.

Acknowledgments: We thank two reviewers for their salient suggestions for improvement.

Conflicts of Interest: The authors declare no conflict of interest.

\section{References}

1. Syvitski, J.P.M.; Kettner, A.J.; Overeem, I.; Hutton, E.W.H.; Hannon, M.T.; Brakenridge, G.R.; Day, J.; Vörösmarty, C.; Saito, Y.; Giosan, L.; et al. Sinking deltas due to human activities. Nat. Geosci. 2009, 2, 681-686. [CrossRef]

2. Besset, M.; Anthony, E.J.; Bouchette, F. Multi-decadal variations in delta shorelines and their relationship to river sediment supply: An assessment and review. Earth-Sci. Rev. 2019, 193, 199-219. [CrossRef]

3. Brondizio, E.S.; Vogt, N.D.; Mansur, A.V.; Anthony, E.J.; Costa, S.; Hetrick, S. A conceptual framework for analyzing deltas as coupled social-ecological systems: An example from the Amazon River Delta. Sustain. Sci. 2016, 11, 591-609. [CrossRef]

4. Day, J.W.; Agboola, J.; Chen, Z.; D’Elia, C.; Forbes, D.L.; Giosan, L.; Kemp, P.; Kuenzer, C.; Lane, R.R.; Ramachandran, R.; et al. Approaches to defining deltaic sustainability in the 21st century. Estuar. Coast. Shelf Sci. 2016, 183, 275-291. [CrossRef]

5. $\quad$ Edmonds, D.A.; Caldwell, R.L.; Brondizio, E.S.; Siani, S.M.O. Coastal flooding will disproportionately impact people on river deltas. Nat. Commun. 2020, 11, 4741. [CrossRef]

6. Luijendijk, A.; Hagenaars, G.; Ranasinghe, R.; Baart, F.; Donchyts, G.; Aarninkhof, S. The state of the world's beaches. Sci. Rep. 2018, 8, 6641. [CrossRef] [PubMed]

7. Pekel, J.-F.; Cottam, A.; Gorelick, N.; Belward, A.S. High-resolution mapping of global surface water and its long-term changes. Nature 2016, 540, 418-422. [CrossRef] [PubMed]

8. Besset, M.; Anthony, E.J.; Sabatier, F. River delta shoreline reworking and erosion in the Mediterranean and Black Seas: The potential roles of fluvial sediment starvation and other factors. Elem. Sci. Anthr. 2017, 5, 54. [CrossRef]

9. Anthony, E.J.; Marriner, N.; Morhange, C. Human influence and the changing geomorphology of Mediterranean deltas and coasts over the last 6000 years: From progradation to destruction phase? Earth-Sci. Rev. 2014, 139, 336-361. [CrossRef]

10. Grill, G.; Lehner, B.; Thieme, M.; Geenen, B.; Tickner, D.; Antonelli, F.; Babu, S.; Borrelli, P.; Cheng, L.; Crochetiere, H.; et al. Mapping the world's free-flowing rivers. Nature 2019, 569, 215-221. [CrossRef] [PubMed]

11. Hzami, A.; Heggy, E.; Amrouni, O.; Mahé, G.; Maanan, M.; Abdeljaouad, S. Alarming coastal vulnerability of the deltaic and sandy beaches of North Africa. Sci. Rep. 2021, 11, 2320. [CrossRef]

12. Provansal, M.; Dufour, S.; Sabatier, F.; Anthony, E.J.; Raccasi, G.; Robresco, S. The geomorphic evolution and sediment balance of the Lower Rhône River (southern France) over the last 130 years: Hydropower dams versus other control factors. Geomorphology 2014, 219, 27-41. [CrossRef] 
13. Pratellesi, M.; Ciavola, P.; Ivalda, R.; Anthony, E.J.; Armaroli, C. River-mouth geomorphological changes over $>130$ years (1882-2014) in a small Mediterranean delta: Is the Magra delta reverting to an estuary? Mar. Geol. 2018, 403, 2-224. [CrossRef]

14. Pickens, A.P.; Hansen, M.C.; Hancher, M.; Stehman, S.V.; Tyukavina, A.; Potapov, P.; Marroquin, B.; Sherani, Z. Mapping and sampling to characterize global inland water dynamics from 1999 to 2018 with full Landsat time-series. Remote Sens. Environ. 2020, 243, 111792. [CrossRef]

15. Snoussi, M.; Haida, S.; Imassi, S. Effects of the construction of dams on the Moulouya and the Sebou rivers (Morocco). Reg. Environ. Chang. 2002, 3, 5-12. [CrossRef]

16. Marriner, N.; Flaux, C.; Morhange, C.; Kaniewski, D. The Nile delta's sinking past: Quantifiable links with Holocene compaction and climate-driven changes in sediment supply? Geology 2012, 40, 1083-1086. [CrossRef]

17. Gebremichael, E.; Sultan, M.; Becker, R.; El Bastawesy, M.; Cherif, O.; Emil, M. Assessing land deformation and sea encroachment in the Nile delta: A radar interferometric and inundation modeling approach. J. Geophys. Res. Solid Earth 2018, 123, 3208-3224. [CrossRef]

18. Bezzi, A.; Pillon, S.; Popesso, C.; Casagrande, G.; Da Lio, C.; Martinucci, D.; Tosi, L.; Fontolan, G. From rapid coastal collapse to slow sedimentary recovery: The morphological ups and downs of the modern Po Delta. Est. Coast. Shelf Sci. 2021, in press.

19. Corbau, C.; Simeoni, U.; Zoccarato, C.; Mantovani, G.; Teatini, P. Coupling land use evolution and subsidence in the Po Delta, Italy: Revising the past occurrence and prospecting the future management challenges. Sci. Total Environ. 2019, 654, 1196-1208. [CrossRef]

20. Bondesan, M.; Castiglioni, G.B.; Elmi, C.; Gabbianelli, G.; Marocco, R.; Pirazzoli, P.A. Coastal areas at risk from storm surges and sea level rise in Northeastern Italy. J. Coast. Res. 1995, 11, 1354-1379.

21. Fiaschi, S.; Fabris, M.; Floris, M.; Achilli, V. Estimation of land subsidence in deltaic areas through differential SAR interferometry: The Po River Delta case study (Northeast Italy). Int. J. Remote Sens. 2016, 39, 8724-8745. [CrossRef]

22. Ninfo, A.; Ciavola, P.; Billi, P. The Po Delta is restarting progradation: Geomorphological evolution based on a 47-years Earth Observation dataset. Sci. Rep. 2018, 8, 3457. [CrossRef] [PubMed]

23. Trincardi, F.; Amorosi, A.; Bosman, A.; Correggiari, A.; Madricardo, F.; Pellegrini, C. Ephemeral rollover points and clinothem evolution in the modern Po Delta based on repeated bathymetric surveys. Basin Res. 2020, 32, 402-418. [CrossRef]

24. Rodriguez-Lloveras, X.; Vilà, M.; Mora, O.; Pérez, F.; Roser, P.; Marturià, J. Detection of subsidence in the Ebro Delta plain using DInSAR: Analysis of the measurements and the factors that control the phenomenon. Proc. Int. Assoc. Hydrol. Sci. 2020, 382, 803-808. [CrossRef]

25. Cogălniceanu, D. Black Sea environmental status improvement through the restoration of wetlands along the Danube River. In Environmental Security in Watersheds; Lagutov, V., Ed.; Book Series: NATO Science for Peace and Security Series C-Environmental Security; Springer: Dordrecht, The Netherlands, 2012; pp. 117-126.

26. Niculescu, S.; Lardeux, C.; Hanganu, J. Alteration and remediation of coastal wetland ecosystems in the Danube delta: A remote-sensing approach. Alter. Remediat. Coast. Wetl. Ecosyst. 2017, 21, 513-554. [CrossRef]

27. Vespremeanu-Stroe, A.; Preoteasa, L.; Hanganu, D.; Brown, A.G.; Bîrzescu, I.; Toms, P.; Timar-Gabor, A. The impact of the Late Holocene coastal changes on the rise and decay of the ancient city of Histria (southern Danube delta). Quat. Int. 2013, 293, 245-256. [CrossRef]

28. Preoteasa, L.; Vespremeanu-Stroe, A.; Tătui, F.; Zăinescu, F.; Timar-Gabor, A.; Cîrdan, I. The evolution of an asymmetric deltaic lobe (Sf. Gheorghe, Danube) in association with cyclic development of the river-mouth bar: Long-term pattern and present adaptations to human-induced sediment depletion. Geomorphology 2016, 253, 59-73. [CrossRef]

29. Zăinescu, F.; Vespremeanu-Stroe, F.; Anthony, E.J.; Tătui, F.; Preoteasa, F.; Mateescu, R. Flood deposition and storm removal of sediments in front of a deltaic wave-influenced river mouth. Mar. Geol. 2019, 417, 106015. [CrossRef]

30. Bini, M.; Casarosa, N.; Luppichini, M. Exploring the relationship between river discharge and coastal erosion: An integrated approach applied to the Pisa coastal plain (Italy). Remote Sens. 2021, 13, 226. [CrossRef]

31. Pranzini, E.; Anfuso, G.; Cinelli, I.; Piccardi, M.; Vitale, G. Shore protection structures increase and evolution on the northern Tuscany coast (Italy): Influence of tourism industry. Water 2018, 10, 1647. [CrossRef]

32. Bertoni, D.; Bini, M.; Luppichini, M.; Cipriani, L.; Carli, A.; Sarti, G. Anthropogenic impact on beach heterogeneity within a littoral cell (northern Tuscany, Italy). J. Mar. Sci. Eng. 2021, 9, 151. [CrossRef]

33. Anthony, E.J. The Human influence on the Mediterranean coast over the last 200 years: A brief appraisal from a geomorphological perspective. Géomorphologie-Relief Process. Environ. 2014, 20, 219-226. [CrossRef] 